\title{
Influence Of Integrated Learning Models Type Connected Assisted Media Images On Results Learning Of Sains
}

\author{
Nurjannah \\ Program Studi PGSD Universitas Negeri Makassar \\ nurjannah@unm.ac.id
}

\begin{abstract}
This study aims to determine differences in the learning outcomes of Sains between students who were taught using integrated learning model connected type of image media with students who were taught using direct instruction model (direc instruction). The population of this study is all students of grade IV SD 237 Mattirobulu Pinrang District 2017/2018 lessons year, which amounted to 186 people. Class samples from this research are 28 students of class IVA as the experimental class and students of grade IVB SD Negri 237 Mattirobulu Pinrang District as many as 28 people as a control class selected by drawing. The research design used is a quasi experimental research design with "Non Equivalent Post-test Only Control Group Design" pattern. Student learning result data is obtained by objective test. Data were analyzed by using descriptive statistical analysis technique and inferential statistic that is t-test. The results of this study show that there is a significant difference of learning outcomes between students who are taught using integrated learning model of assisted type of image connected with students who are taught using direct instruction model. The difference is seen from the results of scores of students' learning achievement of Sains obtained tcount is greater than $t$ table $($ tct $=3.815>$ ttable $=2.021)$ at $5 \%$ significance level. In other words, the integrated learning model of connected type of media-aided image has an effect on students' learning outcomes compared to direct instruction.
\end{abstract}

Keywords: Connected Model, Image, Learning Outcomes of Sains

\section{INTRODUCTION}

Human resources is one of the most decisive components of the nation's fate so that every nation demands its human resources to have insight into science, and can develop Science and Technology (Science and Technology). Development of science and technology is determined by the mastery of the IPA. The technology enjoyed today is largely created through the application of SAINS concepts and principles that are manifested technically in various forms of technology tools and products (Samatowa, 2006). Therefore, the development of the ability of learners in the field of natural sciences is one key to the success of the ability to adapt to changes in the world enter the era of information technology.

Darmojo (in Samatowa, 2006) states that, true knowledge means that knowledge is justified according to the benchmarks of the truth of science, that is rational and objective. Rational sense or logical meaning and objective means in accordance with the object, in accordance with reality, or in accordance with the experience of observation through the five senses. Considering the importance of SAINS in schools and its usefulness in daily life, the government, in this case the Ministry of National Education, seeks to improve the ability of science, such as through the improvement of curriculum of science education from Competency Based Curriculum (KBK) to Education Unit Level Curriculum (KTSP). KBK and KTSP and Curriculum 2013 revised version basically have similarities, where both curriculum are both based on competence. The government also improves educational facilities and infrastructure, improves teachers' teaching methods through teacher upgrading, educational seminars, and teacher certification as an effort to improve the professionalism of teachers that will impact on improving the quality of education. But in reality, the learning that the curriculum is expected has not been realized in the field. This is reinforced based on observations in several public elementary schools in Mattrirobulu Subdistrict Kabupaten Pinrang which consists of State Elementary School No. 231 Mattirobulu, SD Negeri No. 239 Mattirobulu, SD Negeri No. 238 Mattirobulu, 
SD Negeri No 240, SD Negeri No.242 Mattirobulu, and SD Negeri No. 243 Mattirobulu. Based on interview results done, it can be seen that the average score of general scores on science subjects in grade IV are still many who are under the KKM. This means that students' mastery of the subject matter of science has not been mastered properly. From the observation, it is also known that the teacher uses more direct instruction model, which the teacher taught is more oriented with lecture method, less varied, pursue the time to finish the material delivered, less attention to the students ability, less attention to what is delivered can be accepted by students or not, the learning is predominantly teacher-centered or teacher-centered. So that learning in the classroom tends to be boring.

Seeing these problems, teachers need to find the best way to convey the concept of science in the classroom so that learning becomes more fun and more meaningful for students. Teachers should not use a passive or teacher-centered learning model. Teachers desperately need to apply a varied learning model that can inspire students' learning spirit and students can construct their own knowledge (student centred). The disciple should no longer be regarded as a learning object but as a learning subject who must seek and construct his own knowledge. In addition, learning must empower students as much as possible or play an active role in the learning process. Dimyanti and Mudjiono (2002: 3) state "Learning outcomes are a culmination of the learning process. The result of the learning comes from the evaluation of the teacher, and is the result of an interaction of acts of learning and teaching. From the teacher side the teaching action ends with the evaluation process of learning outcomes. From the student side, the learning outcomes, is the end of the peak learning process ". Learning outcomes between students can be different. Slameto (2003) revealed the factors that influence the success of student learning can be divided into 2 groups, namely: 1) Factors that exist in the self itself is called individual factors (internal), which includes (a) biological factors, including: health, nutrition, hearing and vision, (b) phsychological factors, including: intelligence, interest, and motivation and attention of thought memory; (c) fatigue factors, including: physical and spiritual exhaustion, 2) factors that exist outside the individual called factors extern, which includes (a) family factors. The family is the first and foremost educational institution, (b) the school factor, including: teaching methods, curriculum, teacher-student relationships, pupils and school disciplines, (c) community factors, including: students. Another opinion that is in line with the above opinion submitted by Sudjana (2005) which states that the factors that affect student learning outcomes there are two factors that come from within and outside the student self (environmental factors). In addition to the two factors presented earlier there is one more factor that affects the results of student learning that is the quality of teaching in school. The quality of teaching is high or low quality or not the learning process undertaken in the achievement of learning objectives.

Based on some opinions above can be seen that there are factors that affect learning outcomes include internal factors (derived from within the self) and extern (derived from outside the student self). Therefore, to improve science learning outcomes, innovation is needed in the learning activities. In this regard, an integrated type of learning model can be used. The connected model of connected type learning is a model that connects one concept with another concept, one topic with another topic, one skill with another skill, one done in a day with the task done the next day, and the ideas learned. This connected model also obviously connects one concept with another, one with another, one with other skills, one performed on a day with a task done the next, and ideas learned. The integration of the learned ideas in one semester or one quarter with the next semester or quarter becomes a unified whole. With this integration students will link the learned concepts to the relevant fields of science studies (IPA) will form a cognitive scheme, so that children acquire wholeness and unanimity of knowledge. The acquisition of wholeness of science learning, as well as the unanimity of views on life, the real world and natural phenomena can only be reflected through integrated learning.

This learning model is essentially a learning approach that enables learners both individually and actively seeking, digging, and finding concepts and principles in a holistic and authentic way, Ministry of Education (in Trianto, 2007). This learning is a model that tries to integrate several interrelated subjects over a period of time. This integration is aimed to conceptualize the concepts so that the meaningfulness of learning can be achieved.

Integrated learning has several characteristics. The characteristics of 
integrated learning in Trianto (2007: 13) are holistic, meaningful, authentic and active. Moving on from the characteristics of the integrated learning model, the steps taken when the integrated learning model is applied in the science learning involves six phases. Phase 1 is an Introduction, in this phase there are four main activities such as linking learning with previous learning, teachers motivate students, ask students questions related to the concept of prerequisites that must be mastered by students and explain the purpose of learning to students. Phase 2 is the presence of the material, the activities in this phase is the presentation of concepts that must be mastered by students, which includes demonstration activities or presentation skills. The 3rd phase is to guide the training, in this phase the main activity of the teacher is to enable the students to discuss in groups through the help of the LKS and provide guidance and training to the smurid to prepare the report. Phase 4 is to examine the understanding and provide feedback, in this phase the students discuss and then present the results of the discussion and ask other groups to respond to the results of the presentation. After the results of the discussion are addressed, the teacher guides the students in summarizing the topic of discussion. Phase 5 is developing by providing opportunities for advanced training and implementation. In this phase the teacher provides an opportunity for advanced training by providing tasks related to the material. Phase 6 is to analyze and evaluate, in this phase the teacher provides an evaluation to determine the extent to which students have mastered the contents of the material. The integrated learning of connected types according to Hadisubroto (in Trianto, 2007: 44) has several advantages, among others, as follows. 1) With it relationships or links between ideas within a field of study of students have a more comprehensive picture of some aspects they study in more depth, 2) Key concepts developed with sufficient time so that more can be digested by students, 3) Links with a number of ideas in a field of study allowing students to conceptualize and assimilate ideas gradually, 4) Integrated learning of connected types does not interfere with the current curriculum. Integrated learning is one alternative to improve science learning outcomes. To improve the optimality and quality of science learning process required the utilization of a learning medium. Learning media is an element or component of the learning system so that learning media is an integral part of learning. One of the media that can support learning connected is the image media. The image media is the most commonly used learning medium in the learning process and is easy to understand. According to Hamalik (1994) "the media of images is anything that is manifested visually into two dimensional forms as outpourings or minds of various forms such as paintings, portraits, slides, films, strips, opaque projectors". Its concrete nature, making the media more realistic picture shows the subject matter compared to the verbal media alone. The image media can overcome the boundaries of space and time. Not all objects, objects or events can be brought to class, and not always children can be brought to the object or event. With the media images will be able to increase the spirit of students in following the learning process and will be able to improve understanding of concepts that will also impact on the results of science learning. Media images are said to be the perfect medium for instructional media, because the image media has visual elements of image media that have elements of simplicity, integrity, emphasis, balance, shape, graphics, texture and color.

The purpose of this research is to know the effect of integrated learning model of connected type of media aided image to the result of fourth grade student learning at SD Negeri 237 Mattirobulu Kabupaten Pinrang.

\section{RESEARCH METHODS}

This research was conducted in the first semester of the academic year 2017/2018, which was implemented in SD Negeri 237 Mattirobulu Kabupaten Pinrang. This research is quasy experiment because not all variables are strictly controlled. The research design used in this study is non equivalent post-test only control group design. The population in this research is the fourth grader of semester I at SD Negeri 237 Mattirobulu of Pinran Regency which is distributed in six schools namely SD Negeri 231 Mattirobulu class A, SD Negeri 239 Mattirobulu class B, SD Negeri 238 Mattirobulu, SD Negeri 3240 Mattirobulu, SD Negeri 242 Mattirobulu, SD Negeri 246 Mattirobulu, and SD Negeri 248 Mattirobulu, totaling 186 students.

In this study the population members are used as a sample so that the sampling technique used is simple random sampling technique. Of the six primary schools in Mattirobulu District IV, Pinrang District 
selected as a sample is SD Negeri 237 mattirobulu class A of 28 students as experimental class and SD Negeri 1 mattirobulu class B which amounts to 28 students as control class. Having determined two classes as a sample sample equality tests were performed using t-test analysis. After calculation of t-test is obtained tcount $=1.06$ $<$ ttabel $=2.02$ then, $\mathrm{H}_{1}$ is rejected and $\mathrm{H}_{0}$ is accepted which means there is no significant difference of science learning result of students of grade IVA and IVB SD Negeri 237 Mattirobulu. This can be interpreted that the results of the fourth grade students in SD Negeri 237 IV Mattirobulu District are equivalent.

In this study involves one independent variable (Independent Variable) and one dependent variable (Dependent Variable). The independent variable is a learning model consisting of two dimensions ie integrated learning model type conneted with image media and direct learning model without image media. The dependent variable in this study is the result of SAINS students. The data collected in this study is the result of learning science subjects. Data collection in this study using the test method. The test used in this study is a multiple-choice type test. After the instrument is composed, a trial is conducted to get an empirical picture of the feasibility of the instrument in order to be able to used as a research instrument. The test of the instrument performed is a theoretical validity test by two experts, validating multiple choice questions of 40 questions. Furthermore, empirical validity test is analyzed by test: test validity, test reliability, test difficulty level, and test differentiation. After testing instrument, obtained 30 items of valid questions. After the test, the test is given at the end of treatment in the experimental and control classes. The data obtained were then analyzed using descriptive analysis techniques, by finding the mean, median, and mode of the sample data. In addition, the data were also tested with prerequisite test in the form of normality test and homogeneity test. While the method of data analysis used to test the hypothesis is statistical analysis through t-test with the formula polled variance.

\section{RESULT \& DISCUSSION \\ Results \\ To obtain an overview of the learning achievement of Sains, the data were analyzed by descriptive analysis in order to know the Mean (M), Median (Md). Mode (Mo), and standard deviation. The summary of descriptive analysis results is presented in Table 1.}

\begin{tabular}{lll}
\multicolumn{3}{l}{ Table 1. Description of Experimental and Control Group Study Results } \\
\hline Statistics & Experiment group & Control group \\
\hline Mean & 17,96 & 15,21 \\
Median & 18 & 14 \\
Mode & 19,25 & 12,17 \\
Variance & 18,95 & 25,40 \\
Standard deviation & 4,35 & 5,04 \\
\hline
\end{tabular}

Figure 1. Polygon Data Result Post-Test Experimental Group While the control group is known $\mathrm{Mo}<\mathrm{Md}<\mathrm{M}$, and the picture shows a positive cross-sectional graph which means that the student score tends to be low. Based on the conversion of the five-point guidance with the average score $(\mathrm{M} 15.21=54.32 \%)$ is in the moderate category. Description of control group learning outcomes can be seen in Figure 2. 


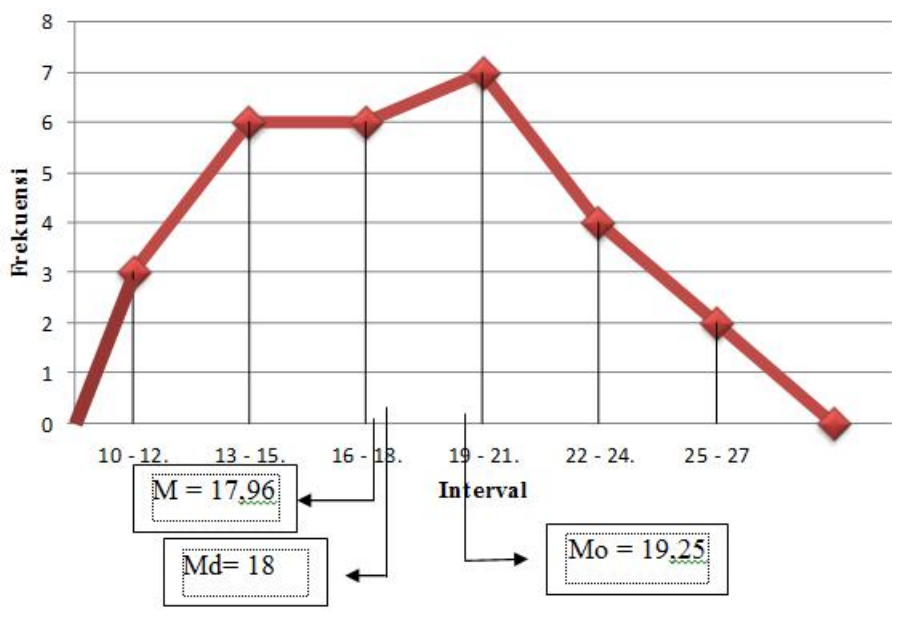

Figure 1. Polygon Data Result Post-Test Experimental Group While the control group

Figure 1. Polygon Data Result Post-Test Experimental Group While the control group is known $\mathrm{Mo}<\mathrm{Md}<\mathrm{M}$, and the picture shows a positive cross-sectional graph which means that the student score tends to be low. Based on the conversion of the five-point guidance with the average score $(\mathrm{M} 15.21=54.32 \%)$ is in the moderate category. Description of control group learning outcomes can be seen in Figure 2.

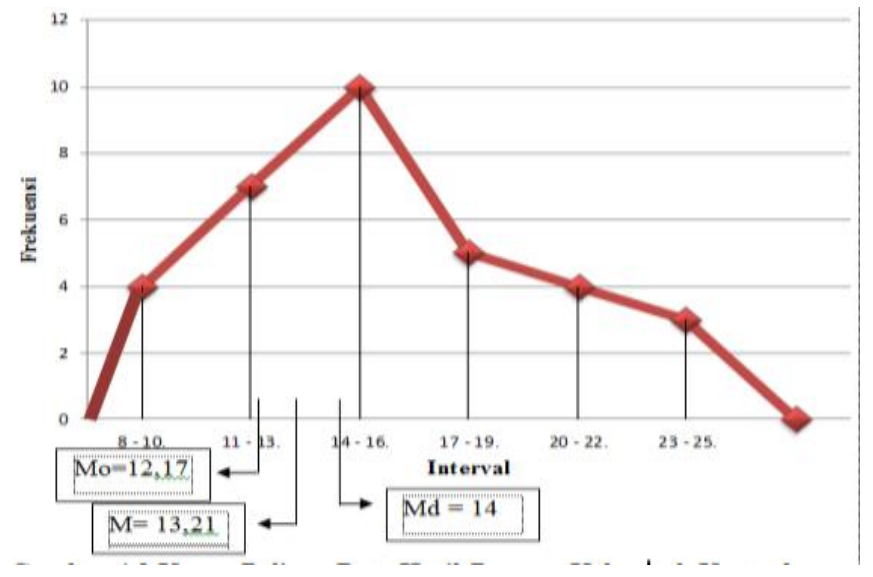

Figure 2. Polygon Data Result Post-test

Control Group Before conducting a hypothesis test, a prerequisite test that includes normality and homogeneity tests is performed. Normality test is done to prove that the data frequency of the research result is really normal distribution. Based on the above table, it is known that the price of $2 \chi$ result post-test of experimental group is 0,877 and $2 \chi$ table with degree of freedom (dk) $=3$ at $5 \%$ significance level is 7,815 . This means $2 \chi$ count the result of post-test experiment group is smaller than $2 \chi$ table $(0,877<7,815)$. So the data of the experimental group's post-test results are normally distributed. While $2 \chi$ count result of post-test of control group is 5,137 and $2 \chi$ table result of control group post-test with degree of freedom $(\mathrm{dk})=3$ at significance level $5 \%$ is 7,815 . This means $2 \chi$ count results post-test control group is smaller than $2 \chi$ table $(0,5,137<7,815)$. So the result data post-test control group is normal distribution. The homogeneity test of variance was performed on pair variance between experimental and control groups. Test used is the $\mathrm{F}$ test with the criterion of homogeneous data if Fhount $<$ Ftabel. Based on the results of homogeneity test analysis obtained Fcount price of 1.34 while Ftabel with dbpembilang $=$ $27, \mathrm{db}$ denominator $=27$, at $5 \%$ significance level is 1.82 This means Fcount is smaller than Ftable $(1.34<1.83)$ so that it can be stated that the data variance of the experimental and control group post-test results is homogeneous.

Hypothesis test is done by using t-test statistic with formula polled variance. The test criterion is $\mathrm{HO}$ denied if thitung $>$ ttable. The 
test is done at the level of significance of $5 \%$ with degrees of freedom $(\mathrm{dk})=\mathrm{n} 1+\mathrm{n} 2-2$.
The summary of t-test results can be seen in Table 2.

Table 2. Results of t-Test Calculations

\begin{tabular}{lllllll}
\hline Data & kelompok & $\mathrm{N}$ & $\mathrm{x}$ & $\mathrm{S}^{2}$ & $\mathrm{~T}_{\text {hitung }}$ & $\mathrm{T}_{\text {tabel (T.S. 5 \%) }}$ \\
\hline Hasil & Eksperimen & 28 & 17,96 & 18,92 & & \\
belajar & kontrol & 28 & 15,21 & 25,40 & 3,815 & 2,021 \\
& & & & & & \\
\hline
\end{tabular}

Based on Table 2, the result of t-test is obtained tcount 3,815 Meanwhile, ttable with $\mathrm{db}=\mathrm{n} 1+\mathrm{n} 2-2=28+28-2=54$ and $5 \%$ significance level is 2.021 . This means, $t$ count is greater than ttable (thitung $>$ ttable), so $\mathrm{H} 0$ is rejected and $\mathrm{H} 1$ is accepted. Thus, it can be interpreted that there are significant differences in learning outcomes in science subjects between students who follow the learning with integrated learning model connected type image media with students who learn to use direct model in SD Negeri 237 Mattirobulu Gugus IV Mattirobulu SubKabupaten Pinrang. To know the influence of integrated learning model of connected media-aided type the drawings with the results of science students of Class IV, can be seen from the average of student learning outcomes in the science lessons between the two sample groups. From the average $(\mathrm{X})$ count, it is known that $\mathrm{X}$ experimental group is 17,96 and $\mathrm{X}$ control group is 15.21 This means, $\mathrm{X}$ experiment is larger than $\mathrm{X}$ control (X experiment> $\mathrm{X}$ control). Based on the findings, it can be concluded that the application of the model integrated learning type connected mediaaided image effect on student learning outcomes on the eyes science lesson of fourth graders in SD Negeri 237 Mattirobulu Gugus IV Mattirobulu Kabupaten Pinrang.

\section{Discussion}

Based on the analysis of the data above, obtained the results of science learning in fourth graders in SD Negeri 237 Mattirobulu Group IV Mattirobulu Kabupaten Pinrang, obtained different results. Students who follow the learning by using integrated learning model type connected media-aided image has the average score of learning outcomes are in the high category and the graph shows negative squint which means the score of students tend to be high. While the results of science learning in fourth graders in SD Negeri 237 Mattirobulu Gugus IV Mattiroabu Kabupaten
Pinrang who followed the learning by using direct model (direct instruction) is in the medium category and the graph shows a positive squint which means the score of students tend to be low. Based on data analysis using t-test statistic statistic that titung is more than ttable. This means that there is a significant difference of science learning outcomes between students who follow integrated learning type connected with image media with students who follow the learning using direct learning model (direct instruction) on the fourth graders in SD Negeri 237 Gugus IV Mattirobulu District, Pinrang District. Learning by using integrated learning model connected type media image, all learning activities are dominated by students. In this learning, students are actively seeking information from various sources through reading activities and discussing with friends of one group. In this learning activity, students are able to link learning materials to one another. So that students have a more comprehensive picture of some specific aspects they learn in more depth. This is in line with opinion. Hadisubroto (in Trianto, 2007: 44). Moreover with the help of image media that makes the insights and creative thinking of students grow. By looking at the picture, of course, the students' visual ability develops well. It was also found that students were very excited and enthusiastic to learn, when learning was associated with other materials related to daily life.

From this also seen the students come up with creative ideas by looking at the picture. According to Hamalik (1994), the image is a visually embodied object that can penetrate the boundaries of space and time, overcoming the limitations of observation, can clarify the problem and be very cheap. So integrated learning connected type media-aided image is very influential on improving student learning outcomes. Learning by using an integrated type of connected learning model emphasizes 
student learning activities through several phases. In the introductory phase there are four main activities such as linking learning with previous learning, teachers motivating students, giving questions to students regarding the concept of prerequisites that must be mastered by students and explain the purpose of learning to students. In the material presenting phase, students present presentations that must be mastered by the students, including demonstration activities or skills presentations. This fosters students' confidence. After that, the guiding phase of the training, in this case, the main activity of the teacher is to enable the students to discuss in groups through the help of the LKS and provide guidance and training to the students to prepare the report. Student insights are more open with guidance from teachers. Also found, many students ask about things that are poorly understood so that the student looks actively asked. In the phase of reviewing the understanding and providing feedback, students are also active to discuss and then present the results of the discussion and ask other groups to respond to the outcome of the presentation. In this activity, students who are mature presentations prepare their performance in front of the class and find creative ideas for presentations smooth and interesting. From this comes a bold attitude and cooperation among students in presenting and responding to other friends' questions, before the teacher guides the students in concluding the topic of discussion. In the next phase that is, develop by providing opportunities for advanced training and application by providing tasks related to the material. So that the pupils are able to remember the material that has been discussed, do the tasks solemnly and the sense of student responsibility arises. Furthermore, in the phase of analyzing and evaluating, the teacher provide evaluation to know the extent to which students have mastered the content of the material. Of course students follow with enthusiasm in order to get high marks.

Unlike the case with direct instruction model (direct instruction) which is dominated by lectures and focusing on the teacher's learning. The steps of direct instruction model start from objective presentation, material demonstration, giving training, giving feedback and giving students the opportunity for advanced training. Indrawati (2005), also explained that in the direct learning, the material is not arranged interconnected with other materials, so less optimal learning.
Activity of teachers who tend to dominate this makes students lazy to explore his mind because students assume that the teacher will explain the material as a whole to the students.

Differences in learning steps between integrated learning model types connected with direct instruction model (direct instruction) will certainly have a different impact on learning outcomes in science subjects. Integrated learning model of connected type gives more opportunity to students to explore a problem with their own thinkers. Problems given by teachers completed by students through discussion. Teachers and students have a harmonious relationship. The teacher gives a presentation of material in the form of a presentation of reading material or demonstration activities. Teachers present learning that has interdependent concept of field of study that can facilitate the students' mind to understand the material. In addition, in the application of integrated learning model connected type assisted with the image media that can minimize the students' mind abstraction by the delivery of information presented by the teacher. Activity ends inferences and evaluations to find out how far students have mastered the material. In doing a pastil activity will find obstacles that can hamper research nets. In this study also encountered constraints derived from students and from the availability of learning tools. These constraints can be seen in the implementation of the learning process in the classroom. Once observed, the behavior of students in learning activities is very diverse. Sometimes there are students who try to interrupt their friends who are learning, so there was a racket in the classroom. In addition, students are also very difficult to express opinions in front of the class, so the teacher should try several times to make students convey his argument. Obstacles in the research also visible from the lack of learning tools in the form of book packages used by students. However, thanks to good cooperation with the school then the constraints can be resolved properly.

The results of this study is also supported by several studies on the application of integrated learning model of connected type. Nisak (2013), conducted a study presented in the science education journal (ePensa), obtained the result that there was an increase in the students' positive responses to integrated SAINS learning devices connected to the subject matter of the excretory system 
for class IV. This is also in line with classroom action research by Suparwati (2011), stating that the implementation of integrated learning of connected types can improve the learning outcomes of Sainssubjects of grade 4 students. Besides that, this type of connected learning study is in line with Kartini research (2011) known that through the application of connected model can improve the learning result of IPS in grade V students. And the application of integrated learning model of connected type that influences student learning outcomes is expressed also in the journal by Fitriani (2012), with the result that integrated learning model of connected type can improve student learning result of grade V SD. Thus, students' learning outcomes on SAINS subjects that are taught by integrated learning model of connected type aided image media will be better than the students who are taught by direct instruction model.

\section{CONCLUSSION}

Based on the results of research and discussion above, it can be concluded that, there is a significant difference between students who are taught by integrated learning model connected type of media images and students who dibelajarkan with direct instruction model to the results of science learning pupil known that thitung $>$ ttable (3.815> 2.021 with a significance level of $5 \%$ ). Based on the results of research, discussion and conclusion above the author put forward some suggestions as follows. 1) For elementary school students to be always actively and actively participate in the learning process so as to gain new knowledge through self-found experience, 2) For teachers to continue in innovative learning to improve professionalism and develop integrated learning model of the type connected in elementary school so as to improve the quality of learning outcomes, 3) For schools, the results of this study can be used as input to improve the management of learning in order to achieve the goals of learning in primary schools as well as a benchmark for improving the quality of schools in making learning innovations in primary schools. 4) It is advisable to other researchers who are interested to conduct further research on integrated learning model of connected type of media-aided image to pay attention to the constraints experienced in this research as a consideration for the improvement and refinement of research to be implemented.

\section{REFERENCE}

Dimyanti and Mudjiono. 2009. Belajar \& Pembelajaran. Jakarta: Rineka Cipta.

Fitriani. 2012. Implementation of Connected Model Bervisi Science Environment Technology Society on Integrated Science Learning. Semarang: UNNES. Available at http://journal.unnes.ac.id/sju/index.php/ usej/article/view/871/896. Unnes Science Education Journal Volume 1 No. 2 of 2012 (pp. 111-118), (accessed on June 11, 2013)

Hamaling. 1994. Media Pendidikan. Bandung: Citra Aditya Bakti.

Indrawati. 2005. Model Pembelajaran Langsung. Bandung: Depdiknas.

Kartini, G. A. H. 2011. Implementation of Integrated Learning Model Type Connected As Efforts To Increase Activity and Achievement of IPS Learning In Grade $V$ Students of SD Negeri 3 Duda Timur Sub District Selat Karangasem Regency Year 2010/2011. Thesis (not published). Department of Primary School Teacher Education. Undiksha Singaraja.

Nisak, K. 2013. Integrated SAINS Learning Device Development Type Connected on Main Material of Excretion System for Class IX SMP. Available at http://ejournal.unesa.ac.id/article/2699/3 7/article.pdf. Journal of Science Education e-Penza. Volume 01 No. 01 of 2013 (pp. 89-91), (accessed on June 11, 2013).

Samatowa, U. 2006. Mengajarkan IPA di Sekolah Dasar. Jakarta: Kementerian Pendidikan Nasional.

Slameto. 2003. Belajar \& Faktor Yang Mempengaruhinya. Jakarta: Rineka Cipta.

Sudjana, N. 2005. Dasar-Dasar Belajar \& Mengajar. Bandung: Sinar Baru.

Suparwati, N. N. 2011. Implementation of Integrated Learning Type Connected to Improve Student Learning outcomes of SainsGrade IV Students Even Semester of the Year 2010/2011 at Elementary School No.1 Banjar Tegal Buleleng District. Thesis (not published). Department of Primary School Teacher Education. Undiksha Singaraja.

Trianto. 2007. Model Pembelajaran Terpadu: Teori dan Praktis. Jakarta: Penerbit Pretasi. 